\title{
MIR181B1 Gene
}

National Cancer Institute

\section{Source}

National Cancer Institute. MIR181B1 Gene. NCI Thesaurus. Code C81770.

This gene is involved in the regulation of gene expression and plays a role in the development of glioma, plasma cell myeloma and chronic lymphocytic leukemia. 